\title{
Bone Marrow Mesenchymal Stem Cells to Improve Damaged Heart Function after Modified Myocardial Infarction Rat Model
}

\author{
Modifiye Edilmiş Miyokardiyal Enfarktüs Rat Modelinden Sonra \\ Hasarlı Kalp Fonksiyonlarının Kemik İliği Mezenşimal Kök \\ Hücreler İle İyileştirilmesi
}

\section{Research Article}

\author{
Esin Akbay*, Handan Sevim', Özer Aylin Gürpınar', Serdar Günaydın², Mehmet Ali Onur ${ }^{1}$ \\ ${ }^{1}$ Hacettepe University, Department of Biology, Beytepe, Ankara, Turkey. \\ ${ }^{2}$ Department of Thoracic and Cardiovascular Surgery, Ankara Numune Training and Research Hospital, Turkey.
}

\section{A B S TR ACT}

\begin{abstract}
A Ithough nowadays the treatment methods were improved, acute myocardial infarction (MI) and heart failure are the most important cardiovascular mortality and morbidity causes. In this study, mesenchymal stem cells (MSCS) collected from the bone marrow was injected into myocardial regeneration areas of the Wistar albino rats with modified ischemic heart model and this areas were investigated by using electrocardiographic (ECG) data and histopathological analysis. In stem cell implementation group, an increase in the amount of vessels and cells were observed. In this group, the amplitudes of P waves, QRS complex and T waves had no changes, whereas there was a significant reduction on $T$ wave duration and heart beat rate reduced significantly $(p \leq 0,001)$. S-T depression increased to normal levels was observed in reference and control groups more than in stem cell implementation group.
\end{abstract}

\section{Key Words}

Ischemia, bone marrow mesenchymal stem cell, cauterization, electrocardiogram.

\section{ÖZET}

\begin{abstract}
kut miyokard infarktüsü ve kalp yetmezliği; tedavideki gelişmelere rağmen günümüzde kardiyovasküler A mortalite ve morbiditenin en önemli nedenlerindendir. Bu çalışmada, modifiye edilmiş iskemik kalp modeli oluşturulan Wistar albino sıçanlarda, kemik iliğinden elde edilen mezenşimal kök hücreler ile rejenere olan miyokardiyal alanlar, elektrokardiyografik (EKG) ve histopatolojik analizler yapılarak gözlenmiştir. Kök hücre uygulama grubunda damar ve hücre sayısında diğer gruplara göre zamana bağlı olarak artış gözlenmiştir. Ayrıca bu grupta EKG verilerinden P dalgası, QRS kompleksi, T dalgası amplitüdleri diğer gruplara göre farklılık göstermezken, T dalgasının süresi ve kalp atım sayısında önemli derecede azalma gözlenmiştir $(p \leq 0,001)$. Referans grubuna göre kontrol grubunda S-T çökmesinde artış gözlenirken, kök hücre uygulama grubunda azalma gözlenmiştir.
\end{abstract}

\section{Anahtar Kelimeler}

İskemi, kemik iliği mezenşimal kök hücreler, koterizasyon, elektrokardiyogram. 


\section{INTRODUCTION}

schemic heart disease is a life-threatening event that may cause sudden cardiac death and heart failure. Even though angioplasty and thrombolytic agents can relieve the symptom of the infarction, no medication or procedure used clinically has shown efficacy in replacing myocardial scar with functioning contractile tissue, thus cardiac dysfunction after myocardial infarction (MI) is still the major worldwide cardiovascular disorder [1]. In this case, there is a need for new therapeutics to regenerate cardiac tissue. Regenerative medicine is focused on the repair, replacement or regeneration of cells, tissues or organs to restore impaired function resulting from any cause. For a long time, the use of cells for transplantation has been restrained by the limited plasticity of somatic cells. Major advances have been permitted by the discovery and isolation of stem cells that harbour the capacity for self-renewal and the potential to differentiate into one or more types of specialized cells. In theory, the ideal cell type for cellular therapy is likely to be a less commited one that can undergo full cardiomyocyte differentiation, enhance angiogenesis, and trigger vasculogenesis. Under the circumstances, mesenchymal stem cells (MSCs) may have essential combination of plasticity and viability.

MSCs-based regenerative therapy is currently regarded as an alternative approach to salvage the MI hearts [1]. MSCs has been shown, in vivo and in vitro, to proliferate extensively and to differentiate not only into osteoblasts, neurons, and skeletal muscle cells but also into vascular endothelial cells and cardiomyocytes [2-7].

Therefore, this study was designed to investigate whether transplantation of MSCs induces myogenesis and angiogenesis, and thereby changes myocardial histomorphology and improves cardiac function in a rat model of myocardial infarction.

\section{MATERIAL AND METHODS}

\section{Isolation, Culturing and Characterization of} Mesenchymal Stem Cells

Male Wistar albino rats (150 and 350 g) were used with the approval of the Animal Care and
Use Committee, Hacettepe University. $150 \mathrm{~g}$ rats were used for cell isolation, characterization, and transplantation. Bone marrow stromal cells were collected from tibias and femurs of rats. After the ether inhalation, both tibias and femurs were removed and their proximal ends were cut. Bone marrow were collected in a centrifuge tube within cell culture medium (Dulbecco's Modified Eagle's Medium-F12, DMEM/F12; Sigma Chemical, USA) containing antibiotics $(0,5 \%$ penicilinstreptomycin). Bone marrow were homogenized by pipetting and centrifuged at $800 \mathrm{rpm}$ for 10 minutes. The marrow pellet were resuspended in cell culture medium (Dulbecco's Modified Eagle's Medium-F12, DMEM-F12) containing 10\% fetal bovine serum (FBS) and antibiotics (0,2\% penicilin-streptomycin) incubated in a humidified atmosphere of $5 \% \mathrm{CO}_{2}$ at $37^{\circ} \mathrm{C}$. The medium was replaced every three days and the non-adherent cells were discarded. The attached cells were incubated in same medium under standard culture conditions. When the cells become confluent, they were trypsinized. The culture medium were removed, and the cells were harvested using a mixture of $0.25 \%$ trypsin- 10 mM EDTA (Biochrom AG, Germany) and the mesenchymal stem cells were passaged three times. All experiments were performed using cells from the third passage.

Cells were confirmed to be MSCs by cell surface markers, CD13-FITC (fluorescein isothiocyanate), CD13-TR (Texas red) (data not shown), CD29-FITC and CD29-TR (Santa Cruz Biotechn., USA) which are specific for MSCs. After cell culture medium was removed, cells were washed with phosphate buffer saline (PBS, Santa Cruz Biotechn., USA). Cells surface were coated with $-10^{\circ} \mathrm{C}$ methanol for 5 minutes for fixation. After washing with PBS for a few times, cells were incubated with primary antibodies (CD13 and CD29) for 60 minutes. After this duration, cells were washed with PBS several times again and after that they were incubated with secondary antibodies (goat anti-mouse IgGFITC and goat anti-mouse IgG-TR) for 45 minutes. At the end of this process, cell surfaces were covered with UltraCruzTM mounting medium (SantaCruz Biotechn., USA) and they were examined under inverted microscope (Olympus IX70 Inverted Microscope, Japan) (Figure 1(a), (b), (c), (d), (e), (f), (g) and (h)). 

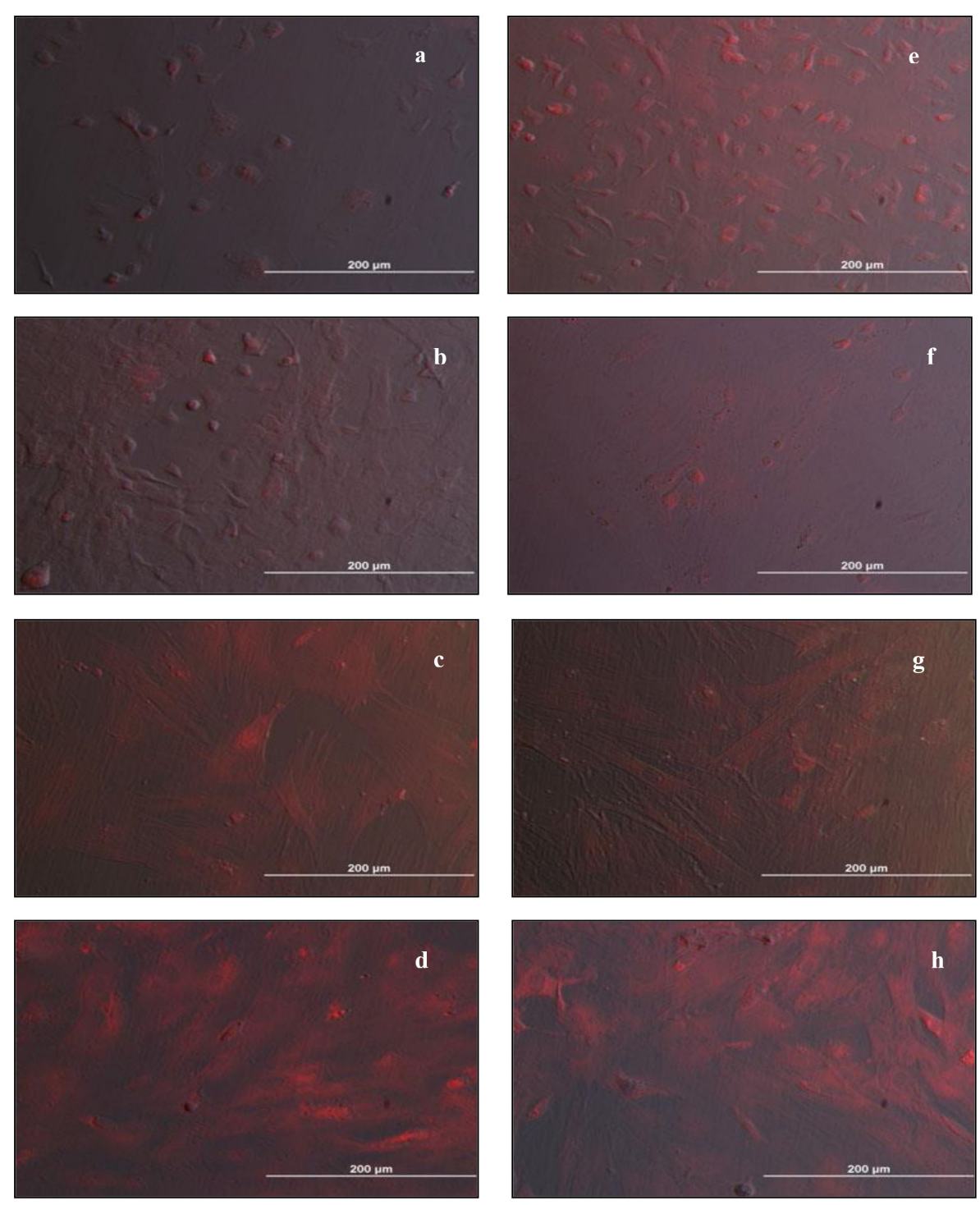

Figure 1. Immunocytochemistry studies for CD29 expression in (a) cells at passage 0, (b) cells at passage 1, (c) cells at passage 2 and (d) cells at passage 3 and CD13 expression in (e) cells at passage 0, (f) cells at passage 1, (g) cells at passage 2 and (h) cells at passage 3 [Protein expression was confirmed by Texas Red (TR) stain - Red color] [Adobe Photoshop CS2 light microscopic and TR fluorescent staining superimpose filter images (545-580 nm)].

\section{Myocardial Infarction Model and MSCs Transplantation}

Experimental MI was induced by cauterization of the left anterior descending coronary artery that a novel modified model described before [8]. 350 $\mathrm{g}$ animals were used for the in vivo study. The rats were divided randomly into three groups: sham-operated group, control group and stem cell implementation group. Briefly, 34 male Wistar albino rats were anesthetized with ketamin (40 $\mathrm{mg} / \mathrm{kg}$ ) and xylazine $(1 \mathrm{mg} / \mathrm{kg}$ ) by intramuscular administration. After the absence of the pedal reflex, the rats were placed in the supine position. Under sterile conditions, the rats were subjected to left lateral thoracotomy between fourth and fifth ribs. The costas were gently retracted to mantain surgical exposure. The pericardium was incised to expose the anterior surface of the heart and the left aterior descending artery was cauterizated at the midpoint through the starting point and the cardiac apex. Correct position of the occlusion was confirmed by S-T segment elevation on the ECG and regional necrosis of the myocardial surface. The control-operated group 


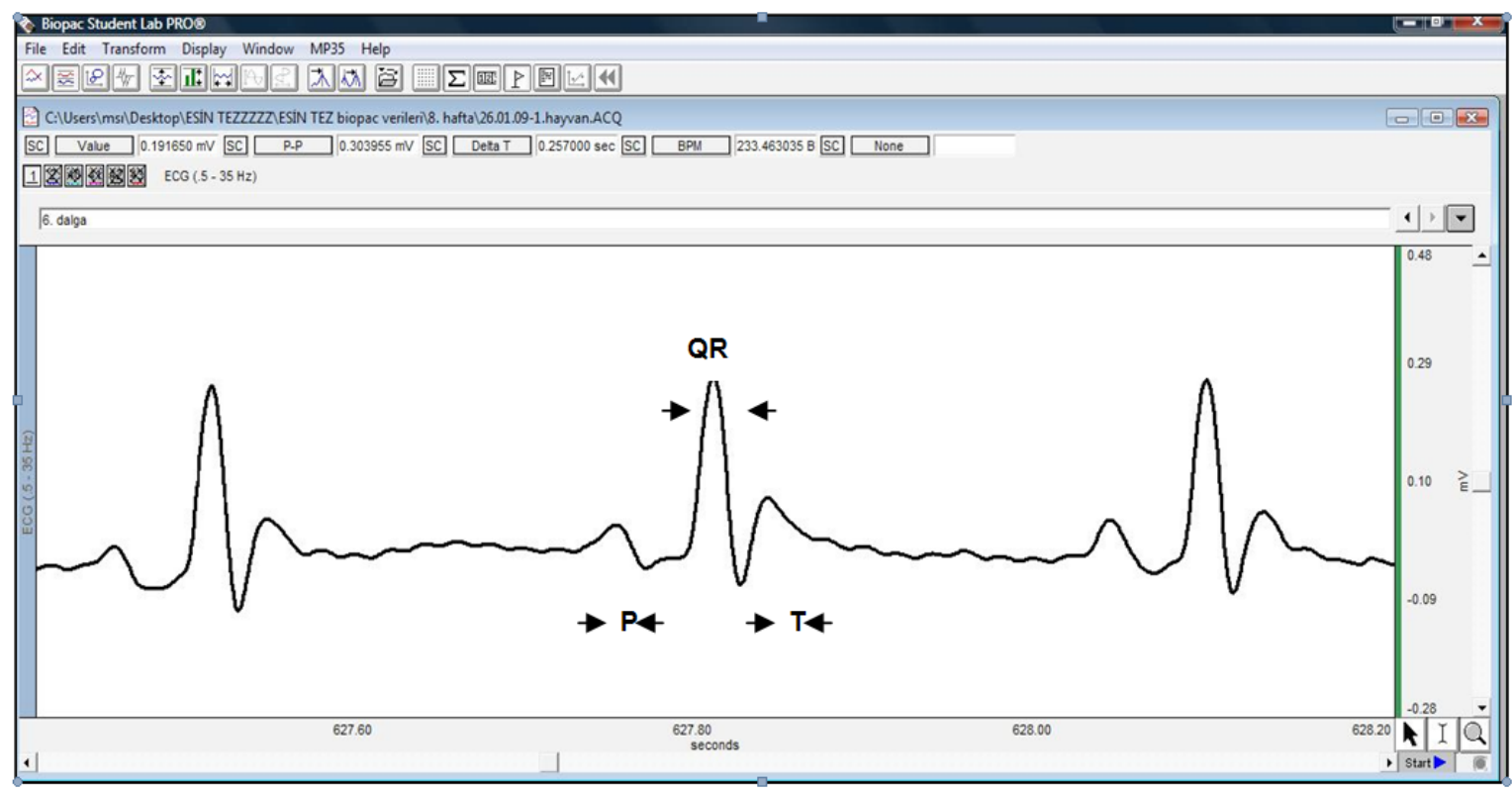

Figure 2. Electrocardiogram sample of rats taken by MP35 data acquisition system (BIOPAC System, Inc.).

received the same procedure of thoracotomy. Five minutess after the cauterization, to the stem cell implementation group a total of $2 \times 104$ MSCs suspended in $100 \mu$ l of PBS were separately injected with a 30-G tuberculin syringe into three different sites for each infarcted area. Controloperated rats received the same volume of PBS injection. The sham group underwent the identical surgery with neither cauterization of the coronary artery nor MSC transplantation.

\section{MP35 Monitorization ve Electrocardiography}

ECG record were taken by MP35 data acquisition system (BIOPAC System, Inc.). For this purpose BSL PRO 3.7 sample files were used. Records were taken over the Channel-1 for ECG 0,5-35 Hz. Records were performed with 200 sample per second, $66,50 \mathrm{~Hz}$ sampling rate and $x 1000$ gain. All records were adjusted for two hours.

Electrocardiographic records were taken from all rats before and during operation and also before sacrification. Standart limb lead electrocardiograms (ECGs) at derivation-II (DII) were monitored throughout the surgical procedure. Body surface ECGs were made with rats in the supine position. ECGs were recorded using three subcutaneously placed needle electrodes: two on each hind limbs and one on right front limb. Electrode on the right hind limb functioned as a reference electrode. The three orthogonal ECG signals were recorded with a $66,50-\mathrm{Hz}$ sampling rate. Registrations were performed with a maximum sample size of 200 sample/second to allow for beat selection and subsequent averaging, further improving the signal-to-noise ratio (Figure 2).

\section{Histopathology}

All rats were sacrified 1, 2, 4 and 8 weeks after cell transplantation. The heart was exposed by median sternotomy and quickly excised and perfused with normal saline. The hearts were cut longitudinally into two equal slice samples. Samples were fixed in 10\% formalin and embeded in parafin and stained with H\&E. Serial sections of $5 \mu \mathrm{m}$ thickness were cut transversely. Ten randomly selected fields per section were analyzed for cell number and capillary density.

The number of microvessels and cells in the infarcted area were counted in parafin-embedded sections with $\mathrm{H} \& \mathrm{E}$ staining under inverted microscope (Olympus IX70 Inverted Microscope, Japan) (magnification $\times 200$ ). Microvessels and cells were counted at the same magnification by Analysis LS Research program (Soft Imaging System, An Olympus Company, Germany). The 


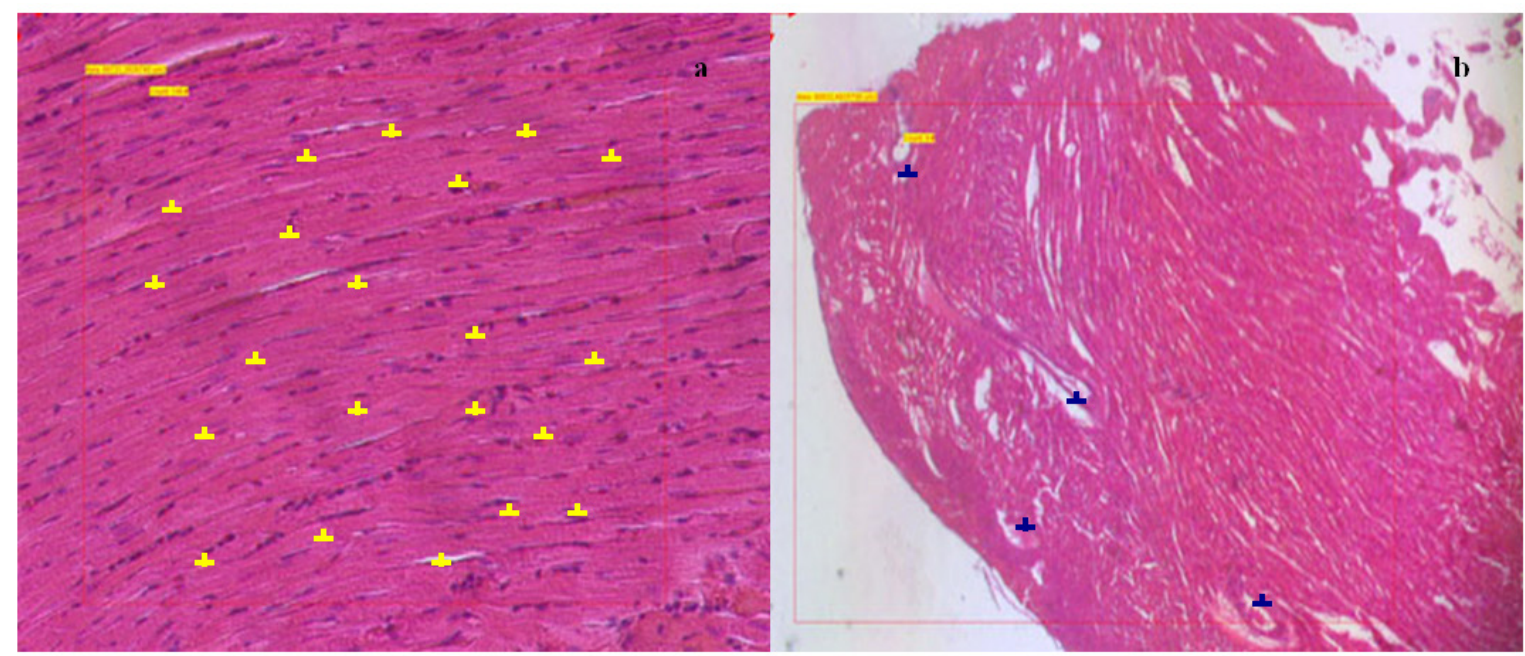

Figure 3. H\&E staining of heart section for quantification of heart muscle cells (nucleus) and small vessels in ischemic area at week $1,2,4$ and 8 . CLI induction $(n=9)$. (a) Cell number of stem cell implementation groups belonging to the fixed field cell counts (+) X200. (b) Capillary number of stem cell implementation groups belonging to the fixed field cell counts (+) X40.

number of samples in each were averaged, vascular and cell densities were expressed as the number of microvessels and cells per unit area $\left(89572,6611 \mu \mathrm{m}^{2}\right)$ (Figure 3).

\section{Statistical Analyses}

Data were presented as mean \pm Standard deviation (SD). Statistical analysis were performed using a one-way ANOVA, and the difference between groups was determined by further analysis with Tukey and Hochberg's GT2 post test (SPSS for window, version 11.5). $\mathrm{P} \leq 0.05$ was considered statistically significant.

\section{RESULT AND DISCUSSIONS}

\section{Isolation, Cultivation and Characterization of MSCs}

Three days after the MSCs were seeded on culture plates, inverted microscope demostrated small colonies of adherent cells with typical fibroblastshaped morphology. These primary cells reached monolayer confluence, after being plated for 7-10 days, when they were passaged for the first time. The cells were noted to have great potential for proliferation after subculture. The fibroblast-like morphology was also maintained after passages and throughout the culture period.
The third passage of MSCs was analyzed by cell surface markers for the expression. Isolated MSCs were characterized by staining CD13 and CD29 antibodies specific for them. The cells were found to be positive for CD13 and CD29.

\section{Sample Size and Mortality}

A total of 34 male Wistar rats were included in this part of the study. A mortality rate of $40 \%$ (14 rats) was observed with a total of 20 rats surviving to the experimental end point at 8 weeks. All of the mortalities occurred during the first $24 \mathrm{~h}$ after coronary occlusion. No late deaths were observed in surviving rats.

\section{Histological Examination}

H\&E sections of heart showed that, in the infarcted area, there was a focal cell infiltration and sarcoplasm condensation (Figure 4). Also in a few area there was a congestion and especially cell border changes were observed in stem cell implementation group under a microscope (Figure 5). Compared to control group the cell borders were thicker in the stem cell implementation group. Sham group tissues exhibited no noticable pathological change.

In stem cell implementation group, the increased amount of vessels and cells were observed. The results showed that MSC 

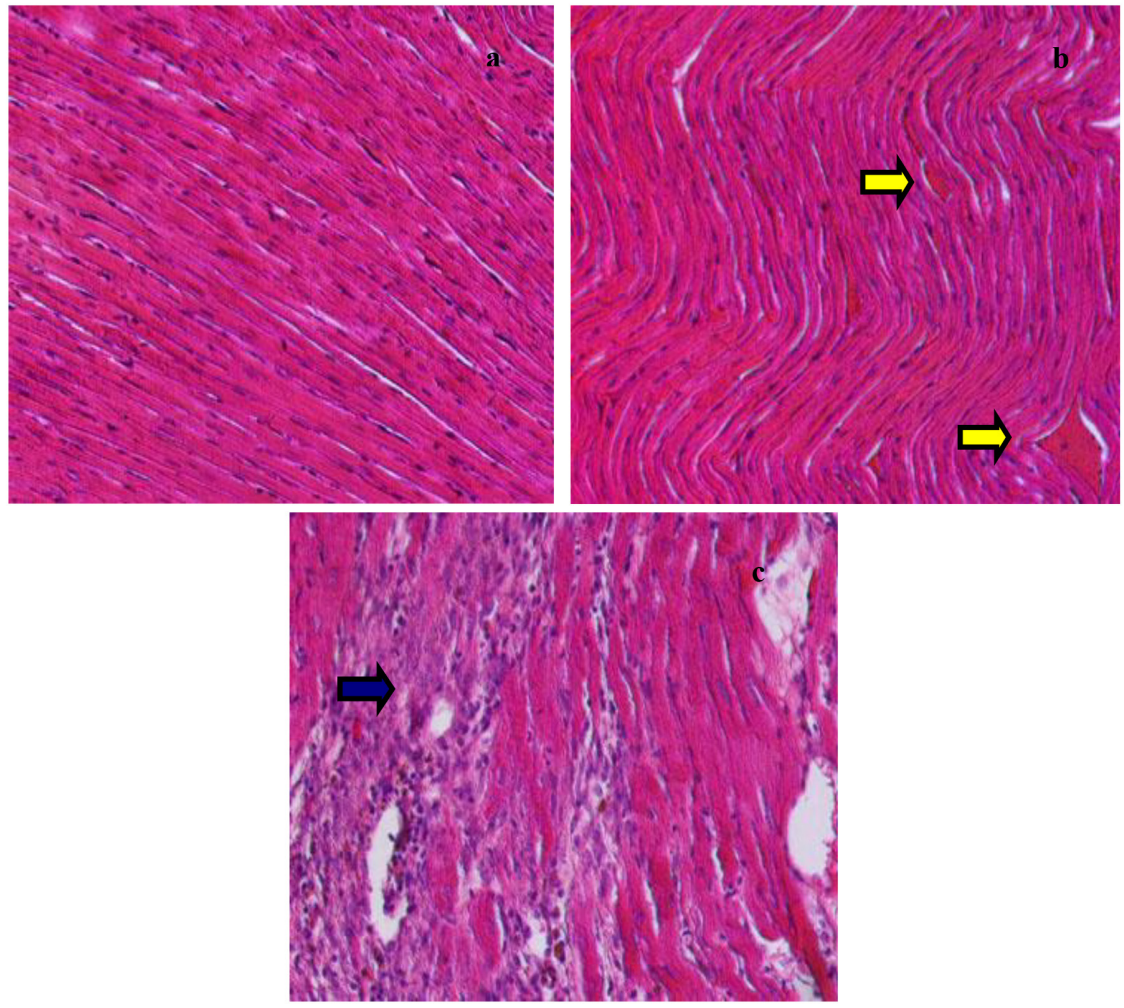

Figure 4. Histopathological staining of heart section (200x) at reference and stem cell implementation groups at day 7. Representative photomicrographs from sections stained with H\&E 1 weeks following coronary cauterization of reference (a) and stem cell implementation groups (b-c) demonstrating a focal cell infiltration (blue arrow) and sarcoplasm condensation (yellow arrow). HPF = highpower field (200x).
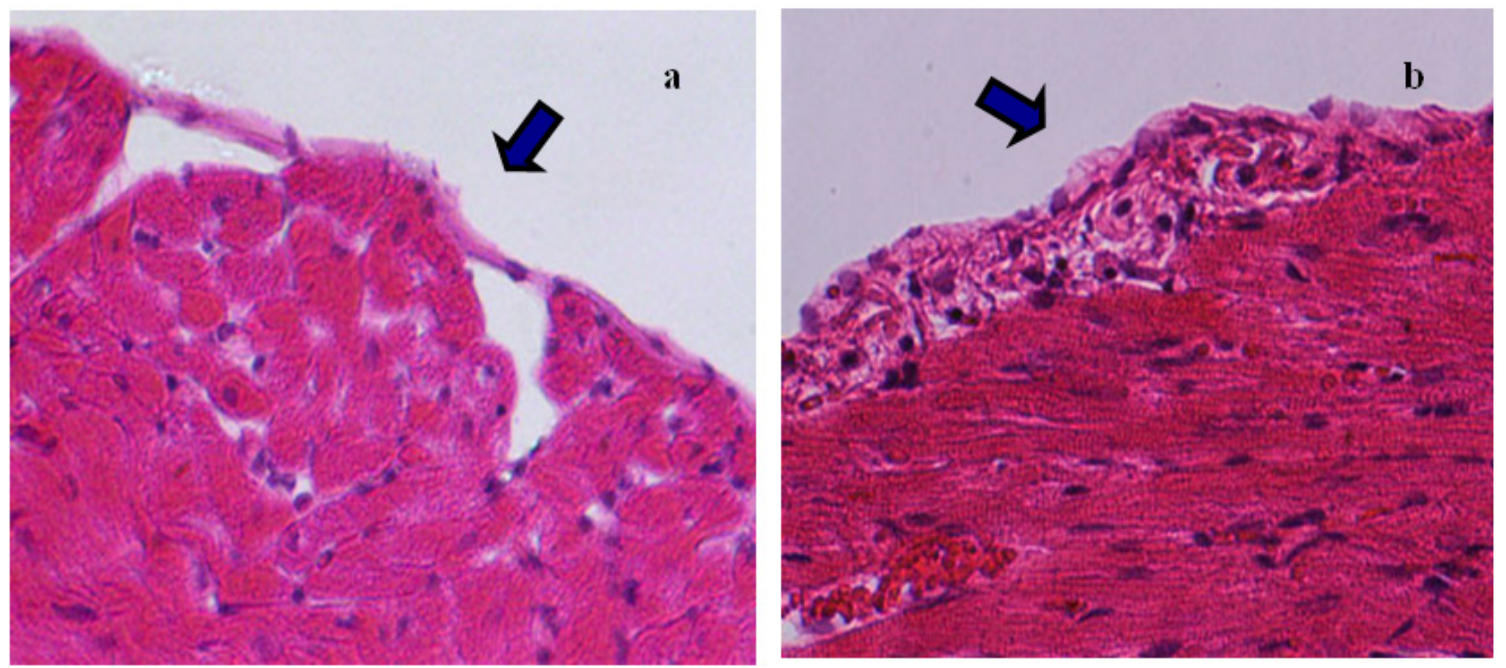

Figure 5. H\&E staining of heart section (400x) of reference and stem cell implementation groups at week 8 . Representative photomicrographs from sections stained with H\&E. 8 weeks following coronary cauterization of reference (a) and stem cell implementation groups (b)mdemonstrating cell border changes. HPF = highpower field (400x). 
Table 1. Cell number of the reference, control and stem cell implementation groups.

\begin{tabular}{ccccc}
\hline Cell number & \multicolumn{3}{c}{ Left side } & \\
\hline & 1st week & 2nd week & 4th week & 8th week \\
\hline Reference & $197.15 \pm 7.73$ & $197.15 \pm 7.73$ & $197.15 \pm 7.73$ & $197.15 \pm 7.73$ \\
\hline Control & $250.00 \pm 15.51$ & $243.25 \pm 17.20$ & $266.25 \pm 8.37$ & $198.00 \pm 4.89$ \\
\hline $\begin{array}{c}\text { Stem Cell Implementation } \\
\text { group }\end{array}$ & $241.40 \pm 6.75$ & $204.93 \pm 7.34$ & $193.33 \pm 7.73$ & $231.80 \pm 6.56$ \\
\hline
\end{tabular}

Table 2. Capillary number of the reference, control and stem cell implementation groups.

\begin{tabular}{ccccc}
\hline Capillary number & \multicolumn{3}{c}{ Left side } & \\
\hline & 1st week & 2nd week & 4th week & 8th week \\
\hline Reference & $3.95 \pm 0.29$ & $3.95 \pm 0.29$ & $3.95 \pm 0.29$ & $3.95 \pm 0.29$ \\
\hline Control & $5.75 \pm 0.85$ & $5.00 \pm 0.00$ & $5.00 \pm 0.00$ & $4.00 \pm 0.40$ \\
\hline $\begin{array}{c}\text { Stem Cell } \\
\begin{array}{c}\text { Impmentation } \\
\text { group }\end{array}\end{array}$ & $3.73 \pm 0.39$ & $5.73 \pm 0.67^{\text {a }}$ & $7.00 \pm 0.60^{\text {a }}$ & $7.13 \pm 0.44^{\mathrm{a}, \mathrm{b}}$ \\
\hline
\end{tabular}

a: Significantly different from Reference group ( $p \leq 0.001)$.

b: Significantly different from control group $(p \leq 0.001)$.

transplantation increased vessel density and this increase was significantly greater in 8 week stem cell implementation group compared to control and sham groups $(p \leq 0,001)$. These results are also same for cell density measurement (Tables 1 and 2).

\section{Electrocardiographic Assessment of Cardiac Function}

Electrocardiographic assessments in vivo were obtained in $\mathrm{Ml}$ and control groups before operation, during operation and after operation at $1 \mathrm{st}, 2 \mathrm{nd}, 4$ th and 8 th weeks. The ECG waves showed significant differences among the $\mathrm{Ml}$ rats and sham-operated animals. In stem cell implementation group, the amplitudes of $P$ waves, QRS complex and T waves had no changes, whereas there was a significant reduction on $T$ wave duration and heart beat rate reduced also significantly $(p \leq 0,001)$ (Table 3$)$. S-T depression increased to normal levels was observed in reference and control groups more than in stem cell implementation group (Figure 6).

\section{DISCUSSION}

Bone marrow is a rich reservoir of stem cells and progenitor cells. Theis reservoir include a population of MSCs, which have been shown to proliferate extensively in vivo and in vitro and, when cued by the appropriate microenviroment, to differentiate along multiple lineages giving rise to muscle, brain, liver, cartilage, bone, fat, and blood vessels [2,9-13]. Toma et al reported that the relatively purified MSCs engrafted in the myocardium appeared to differentiate into cardiomycyte [14]. Thus, MSCs are commonly used in transplantation to repair the ripped myocardium with all these features.

Cell necrosis after an injury such as MI may cause the release of signals into circulatory system, and these could induce the homing of stem cells to the myocardium [15-17]. The intense inflammatory reaction after MI may cause a local accumulation of mast cells, which might also contribute to the homing of MSCs $[6,18-20]$. The injured tissue may express receptors or ligands that facilitate the trafficking and adhesion of stem cells to the site of injury, where differentiation is 
Table 3. ECG parameters of stem cell implementation and reference groups.

\begin{tabular}{cccccc}
\hline & 1st week & 2nd week & 4th week & 8th week & Reference \\
\hline $\begin{array}{c}\text { P wave } \\
\text { amplitude (mV) }\end{array}$ & $0.037 \pm 0.001$ & $0.040 \pm 0.001$ & $0.039 \pm 0.001$ & $0.049 \pm 0.014$ & $0.043 \pm 0.001$ \\
\hline $\begin{array}{c}\text { QRS complex } \\
\text { amplitude (mV) }\end{array}$ & $0.249 \pm 0.007$ & $0.271 \pm 0.007$ & $0.280 \pm 0.006$ & $0.294 \pm 0.012$ & $0.264 \pm 0.005$ \\
\hline $\begin{array}{c}\text { QRS complex } \\
\text { time (sec) }\end{array}$ & $0.031 \pm 0.000$ & $0.034 \pm 0.001$ & $0.031 \pm 0.000$ & $0.033 \pm 0.000$ & $0.032 \pm 0.000$ \\
\hline $\begin{array}{c}\text { T wave } \\
\text { amplitude (mV) }\end{array}$ & $0.122 \pm 0.007$ & $0.082 \pm 0.008$ & $0.117 \pm 0.010$ & $0.102 \pm 0.007$ & $0.087 \pm 0.003$ \\
\hline $\begin{array}{c}\text { T wave time } \\
\text { (sec) }\end{array}$ & $0.035 \pm 0.001^{\mathrm{a}}$ & $0.025 \pm 0.000$ & $0.043 \pm 0.003$ & $0.033 \pm 0.001$ & $1.162 \pm 1.132$ \\
\hline $\begin{array}{c}\text { Beat per Minute } \\
\text { (BPM) }\end{array}$ & $221.1 \pm 3.496^{\mathrm{a}}$ & $223.4 \pm 4.050^{\mathrm{a}}$ & $243.2 \pm 13.906^{\mathrm{a}}$ & $241.4 \pm 8.967^{\mathrm{a}}$ & $280.0 \pm 4.833$
\end{tabular}

a: Statistically significant $(p \leq 0.05)$.

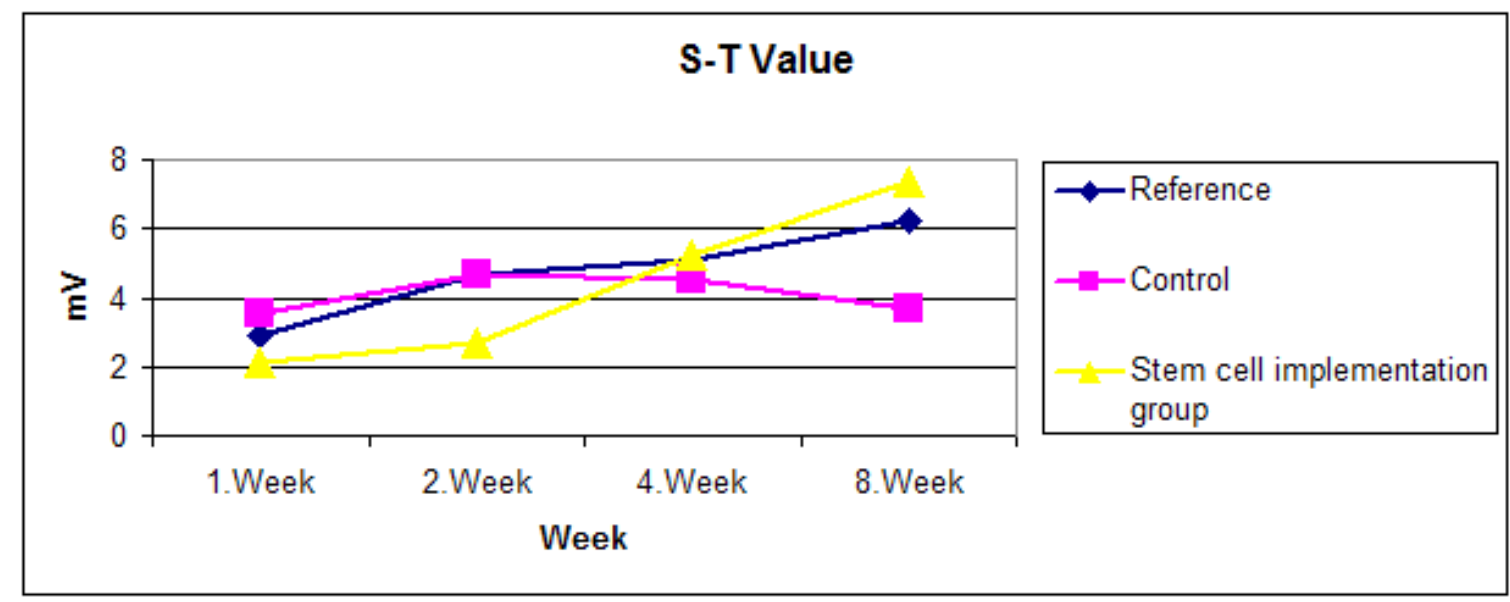

Figure 6. Changes of S-T derivation of reference, control and stem cell implementation groups during the different weeks.

initiated, resulting in the generation of cells of the appropriate lineage [21]. However, it is still unclear what enviromental cues initiate the homing of MSCs to the ischemic heart.

This is consistent with previous studies, which demostrated the capacity of MSCs to give rise to new myocytes, smooth muscle cells, and endothelial cells in ischemic myocardium $[22,23]$. The optimal amount of MSCs for transplantation to improve heart function and attenuate ventricular remodeling in the greatest extent is still not determined. Hou et al reported that $2 \times 10^{6}$ cell/50 $\mu$ I PBS affect the improvement of vessels density [24]. It was shown that $1 \times 10^{7}$ cell/500 $\mu$ l PBS not affected the restoration of the number of cells but affected the progression of the vessel density $[3,4,25]$. In the light of these, this study demostrated that $2 \times 10^{4}$ cell/100 $\mu$ PBS can increase vessel density, attenuate cardiomyocyte apoptosis and improve heart function.

In studies on timing for MSCs injection and scheduling the analysis after therapy, Hou et al proposed that 8 weeks is ideal for seen the differences between groups in terms of angiogenesis [24]. Also our data indicated that 8 weeks provided the optimal timing for MSCS therapy that shown by capillary density in implementation groups.

Although ischemia induces VEGF expression and angiogenesis, blood supply is far from enough for tissue repair. As a result, ischemia 
and anoxia may cause myocardial infarction in the end. MSCs secrete a variety of cytokines including VEGF. Thus MSCs can be transplanted into the infarcted myocardium. The VEGF secreted by MSCs will induce angiogenesis, which will increase regional blood flow to ischemia tissue and reduce infarct area [5,12,13,25-29]. In this study, results demostrated that two months after MSCs transplantation, the vessel density of the stem cell implementation group varied greatly from that of the control and sham groups.

In this study, stem cell implementation were increased capillary density in the myocardium. Quantitive analysis demostrated that capillary density was significantly higher in the stem cell implementation group at eight weeks compared with those in control and sham groups. Improvement in myocardial vascular supply has been shown to decrease necrosis and inflammation in MI. The previous study done by Nagaya et al reported that increased capillary density was associating with improved cardiac function and decreased infarct size following MSC transplantation in a rat model of MI [11]. These results propose that MSC-induced neovascularization may have contributed to the improvement of heart histopathology in this rat model of MI.

The present study evaluated that the functional improvement seen after MSC transplantation after two months by electrocardiographic analysis. Stem cell implementation group showed the expected return to baseline in S-T deviation. These results suggested that MSC transplantation might support myocardial regeneration and provide partial recovery of ischemic area.

An understanding of the limitations of the in vivo study is important to better understand the significance of the results. We did not attempt some quantitive analysis like left ventricular ejection fraction values and wall thickness in our study, which was a limitation of this research.

In conclusion, MSC transplantation was beneficial for the myocardial regeneration in experimental rats. The present study only assessed the short-term effects of transplant MSC. Long-term studies task for the future to find the most practical and specific ways of improving the targeting including labeling the cells and tracking and thereafter detect the effectiveness of stem cell therapy. Also further experiments are required to optimize the location of transplantation of the cells after delivery to heart.

\section{ACKNOWLEDGEMENTS}

This study is a part of Esin Akbay's master thesis and was supported by Hacettepe University Foundation Project No: 07.01.601.002.

\section{References}

1. L.C. Amado, A.P. Saliaris, K.H. Schuleri et al. Cardiac repair with intramyocardial injection of allogeneic mesenchymal stem cells after myocardial infarction, P.N.A.S., 102 (2005) 11474-11479.

2. W. Dai, L.J. Field, M. Rubart et al. Survival and maturation of human embryonic stem cell-derived cardiomyocytes in rat hearts, J. Mol. Cell Cardiol., 43 (2007) 504-516.

3. W. Jiang, A. Ma, T. Wang et al. Homing and differentiation of mesenchymal stem cells delivered intravenously to ischemic myocardium in vivo: a time-series study, Pfluger Arch-Eur. J. Physiol., 453 (2006) 43-52.

4. W. Jiang, A. Ma, T. Wang et al. Intravenous transplantation of mesenchymal stem cells improves cardiac performance after acute myocardial ischemia in female rats, European Society for Organ Transplantation, 19 (2006) 570-580.

5. S. Miyagawa, Y. Sawa, S. Taketani et al. Myocardial regeneration therapy for heart failure: hepatocyte growth factor enhances the effects of cellular cardiomyoplasty, Circulation, 105 (2002) 2556-2561.

6. E.C. Perin. Stem cell therapy for cardiovascular disease, Tex. Heart Inst. J., 33 (2006) 204-208.

7. M.A. Pfeffer, M.C. Fishbein, P.J. Fletcher et al., Myocardial infarct size and ventricular function in rats, Circ. Res., 44 (1979) 503-512.

8. E. Akbay and M.A. Onur, A new modified myocardial infarction animal model, Journal-Cardiovascular Surgery, 1 (2013) 69-71.

9. W. Dai, S.L. Hale, B.J. Martin et al., Allogeneic mesenchymal stem cell transplantation in postinfarcted rat myocardium: Short- and long-term effects, Circulation, 112 (2005) 214-223.

10. Y. Jiang, B.N. Jahagirdar, R.L. Reinhardt et al., Pluripotency of mesenchymal stem cells derived from adult marrow, Nature, 418 (2002) 41-49.

11. N. Nagaya, K. Kangawa, T. Itoh et al., Transplantation of mesenchymal stem cells improves cardiac function in a rat model of dilated cardiomyopathy, Circulation, 112 (2005) 1128-1135.

12. M.F. Pittenger and B.J. Martin, Mesenchymal stem cells and their potential as cardiac therapeutics, Circ. Res., 95 (2004) 9-20. 
13. M.F. Pittenger, A.M. Mackayi, S.C. Beck, Multilineage potential of adult human mesenchymal stem cells, Science, 284 (1999) 143-147.

14. C. Toma, M.F. Pittenger, K.S. Cahil et al., Human mesenchymal stem cells differentiate to a cardiomyocyte phenotype in the adult murine heart Circulation, 105 (2002) 93-98.

15. J. Wang, R. Luo, X. Zhang $X$ et al., Bone marrow mesenchymal stem cell transplantation combined with perindopril treatment attenuates infarction remodelling in a rat model of acute myocardial infarction, J. Zhejiang Univ. Science B. 7 (2006) 641 647.

16. Z. Xie, M. Singh, K. Singh, Differential regulation of matrix metalloproteinase-2 and -9 expression and activity in adult rat cardiac fibroblasts in response to interleukin-1 beta. J. Biol. Chem., 279 (2004) 39513-9.

17. Y.W. Yang, H. Bai, C.B. Wang et al., Experimental study on influence of bone marrow mesenchymal stem cells on activation and function of mouse perioneal macrophages, Zhonghua Xue Ye Xue Za Zhi, 29 (2008) 540-543.

18. E.C. Perin, The use of stem cell therapy for cardiovascular disease, Tex. Heart Inst. J., 32 (2005) 390-392.

19. S. Schenk, N. Mal, A. Finan et al., Monocyte chemotactic protein-3 is a myocardial mesenchymal stem cell homing factor, Stem Cells, 25 (2007) 245251.

20. N.S. Ye, J. Chen, G.A. Luo et al., Proteomic profiling of rat bone marrow mesenchymal stem cells induced by 5-azacytidine, Stem Cells Dev., 15 (2006) 665-676.

21. K.E. Porter, N.E. Turner, D.J. O'Regan et al., Tumor necrosis factor alpha induces human atrial myofibroblats proliferation, invasion and MMP-9 secretion: inhibition by simvastation, Cardiovascular Research, 64 (2004) 507-515.
22. S. Makino, K. Fukuda, S. Miyoshi et al., Cardiomyocytes can be generated from marrow stromal cells in vitro, The Journal of Clinical Investigation, 5 (1999) 697705.

23. D. Orlic, J.M. Hill, A.E. Arai, Stem cells for myocardial regeneration, Circ. Res., 91 (2002) 1092-1102.

24. M. Hou, K. Yang, H. Zhang et al., Transplantation of mesenchymal stem cells from human bone marrow improves damaged heart function in rats, International Journal of Cardiology, 115 (2007) 220228.

25. J. Tang, Q. Xie, G. Pan et al., Mesenchymal stem cells participate in angiogenesis and improve heart function in rat model of myocardial ischemia with reperfusion, European Journal of Cardio-thoracic Surgery, 30 (2006) 353-361.

26. Y.L. Tang, Q. Zhao, Y.C. Zhang et al., Autologous mesenchymal stem cell transplantation induce VEGF and neovascularization in ischemic myocardium, Regul. Pept., 117 (2004) 3-1.

27. 27. S. Tomita, R. Li, R.D. Weisel et al., Autologous Transplantaion of Bone Marrow Cells Improves Damaged Heart Function, Circulation, 100 (1999) 247-256.

28. S. Tomita, D.A. Mickle, R.D. Weisel et al., Improved heart function with myogenesis and angiogenesis after autologous porcine bone marrow stromal cell transplantation, J. Thorac. Cardiovasc. Surg., 123 (2002) 1132-1140.

29. J.S. Wang, D. Shum-Tim, J. Galipeau et al., Marrow stromal cells for cellular cardiomyoplasty feasibility and potential clinical advantages, J. Thorac. Cardiovasc., 120 (2000) 999-1005. 